\title{
PERGESERAN STRATEGI PEMASARAN TRADISIONAL MENUJU PEMASARAN DIGITAL PADA MASA PANDEMI COVID-19
}

\author{
M Usman Maliki \\ Fakultas Ekonomi Universitas Palembang \\ Email : ejausman7686@gmail.com
}

\begin{abstract}
ABSTRAK
Artikel yang berjudul Pergeseran Strategi Pemasaran Tradisional Menuju Pemasaran Digital ini membahas mengenai dampak yang diakibatkan oleh pandemi covid-19 yang melanda dunia ini khususnya di Indonesia sejak awal tahun 2020. Ada banyak aspek yang terkena dampak pandemi ini termasuk turunnya tingkat perdagangan dan penjualan, peningkatan pengangguran serta aspek lainnya yang berkaitan dengan berubahnya strategi pemasaran bisnis di Indonesia menuju strategi digital. Tujuan daripada penelitian ini adalah untuk mengkaji strategi bisnis yang sekiranya dapat menjadi solusi dalam peningkatan perekonomian masyarakat melalui perubahan strategi pemasaran di masa pandemi covid-19. Dalam penelitian ini digunakan penelitian kepustakaan yang dalam proses pengambilan datanya tidak terjun secara langsung tetapi dengan mengambil berbagai sumber referensi yang mendukung suatu penelitian. Teknik pengumpulan data dengan penyimak serta mencatat informasi penting yang berkaitan dengan judul artikel ini. Pandemi covid-19 ini telah memporak porandakan berbagai aspek termasuk penjualan eceran, retail serta jenis perdagangan lainnya. Oleh karena itu perubahan strategi pemasaran menjadi salah satu solusi yang disuguhkan untuk mengembalikan kesehatan perekonomian di Indonesia dengan mengikuti perkembangan zaman, teknologi dan informasi.
\end{abstract}

Kata Kunci : Strategi Pemasaran, Pemasaran Digital, Pandemi Covid-19.

\begin{abstract}
This article, entitled Shifting Traditional Marketing Strategies Towards Digital Marketing, discusses the impact caused by the covid-19 pandemic that has hit the world, especially in Indonesia since the beginning of 2020. There are many aspects that have been affected by this pandemic including declining levels of trade and sales, increasing unemployment. as well as other aspects related to changing business marketing strategies in Indonesia towards digital strategies. The purpose of this research is to examine business strategies that can be a solution in improving the community's economy through changes in marketing strategies during the COVID-19 pandemic. In this study used library research which in the process of data collection does not go directly but by taking various reference sources that support a research. The technique of collecting data with listeners and recording important information related to the title of this article. The COVID-19 pandemic has ravaged various aspects including retail sales, retail and other types of trade. Therefore, a change in marketing strategy is one of the solutions presented to restore economic health in Indonesia by following the times, technology and information.
\end{abstract}

Keywords : Marketing Strategy, Digital Marketing, Covid-19. 


\section{Pendahuluan}

Dalam kehidupan sehari-hari, kita tidak luput dari kabar seputar politik dan ekonomi. Hal ini disebabkan karena memang politik dan ekonomi adalah suatu basis yang bermuara kepada berbagai aspek kehidupan. Dalam kesempatan ini saya berkesempatan untuk menyuguhkan suatu artikel singkat mengenai bisnis digital. Saya mendapat gagasan mengenai bisnis digital dari pengalaman serta melihat situasi dan kondisi. Bisnis dalam era pandemi sekarang ini seharusnya mempunyai peran dalam meningkatkan kesejahteraan yang dibutuhkan oleh masyarakat. Pandemi Covid-19 telah merenggut berbagai macam aspek kehidupan mulai dari meningkatnya tingkat pengangguran, menurunya tingkat kesejahteraan sampai ketidakseimbangan perekonomian di berbagai negara.

Ketertarikan dalam mengambil variabel Pergeseran nilai adalah karena sangat ideal dengan situasi dan kondisi ekonomi di dunia pada saat ini, dimana pandemi covid-19 menurunkan tingkat pemasaran tradisional. Hal ini berakibat terhadap kesejahteraan rakyat dalam skala besar. Kegiatan bisnis yang sedang mengalami proses pengembangan sedemikian rupa itu membutuhkan sistem keteraturan. Ketika kemajuan teknologi membawa bidang enterpreneur ke arah kemajuan dalam hal digitalisasi, ketika itu juga suatu penyesuaian dibutuhkan. Saya melalui artikel ini akan menjelaskan tentang perubahan strategi pemasaran sehubungan dengan melandanya pandemi covid-19.

\section{Landasan Teori}

Menurut Rangkuti (2006), strategi pemasaran adalah serangkaian tujuan atau sasaran, kebijakan dan aturan yang memberi arah kepada usaha-usaha pemasaran perusahaan dari waktu kewaktu pada masing-masing tingkatan dan acuan serta alokasinya, terutama sebagai tanggapan perusahaan dalam menghadapi lingkungan dan keadaan persaingan yang selalu berubah.

$$
\text { Menurut Wijaya dan Iriani }
$$

(2013), strategi pemasaran adalah

himpunan asas yang secara tepat, konsisten, dan layak dilaksanakan oleh perusahaan guna mencapai sasaran pasar yang dituju (target market) dalam jangka panjang dan tujuan perusahaan jangka panjang (objectives) dalam situasi persaingan tertentu. Menurut Assauri (2011), secara umum strategi pemasaran terdiri dari tiga jenis, yaitu:

a. Strategi pemasaran yang tidak membeda bedakan pasar (Undifferentiated marketing).

Dengan strategiini, perusahaan menganggap pasar sebagai suatu keseluruhan, sehingga perusahaan hanya memperhatikan kebutuhan konsumen secara umum. Oleh karena itu perusahaan hanya menghasilkan dan memasarkan satu macam produk saja dan berusaha menarik semua pembeli dan calon pembeli dengan suatu rencana pemasaran saja. Strategi ini bertujuan untuk melakukan penjualan secara massal sehingga menurunkan biaya. Perusahaan memusatkan perhatiannya pada seluruh konsumen dan kebutuhannya serta merancang produk yang dapat menarik sebanyak mungkin para konsumen tersebut.

b. Strategi pemasaran yang membeda bedakan pasar (Differentiated marketin).

Dengan strategi ini, perusahaan hanya melayani kebutuhan beberapa kelompok konsumen tertentu dengan jenis produk tertentu pula. Jadi perusahaan atau produsen 
menghasilkan dan memasarkan produk yang berbeda-beda untuk tiap segmen pasar. Dengan kata lain, perusahaan atau produsen menawarkan berbagai variasi produk dan produk mix, yang disesuaikan dengan kebutuhan dan keinginan kelompok konsumen atau pembeli yang berbeda-beda dengan program pemasaran yang tersendiri diharapkan dapat dicapai tingkat penjualan yang tertinggi dalam masing -masing segmen pasar tersebut.

c. Strategi pemasaran yang ekonsentrasi (Concentrated marketing)

Dengan strategi ini, perusahaan mengkhususkan produknya dalam beberapa segmen pasar dengan pertimbangan keterbatasan sumber daya perusahaan. Dalam hal ini perusahaan produsen memilih segmen pasar tertentu dan menawarkan produk yang sesuai dengan kebutuhan dan keinginan kelompok konsumen yang ada pada segmen pasar itu, yang tentunya lebih spesifik. Strategi pemasaran ini mengutamakan seluruh usaha pemasaran pada satu atau beberapa segmen pasar tertentu saja. Jadi perusahaan memutuskan segala kegiatan akan memberikan keuntungan yang terbesar.

Menurut Tjiptono (2004), terdapat lima langkah yang saling terkait dalam strategi pemasaran, yaitu:

1. Pemilihan pasar, dimulai dengan melakukan segmentasi pasar dan kemudian memilih pasar sasaran yang paling memungkinkan untuk dilayani oleh perusahaan.

2. Perencanaan produk, meliputi produk itu sendiri, nama merek produk, ketersediaan produk, jaminan atau garansi, jasa reparasi dan bantuan teknis yang disediakan penjual, serta hubungan personal yang mungkin terbentuk diantara pembeli dan penjual.

3. Penetapan harga, yaitu menentukan harga yang dapat mencerminkan nilai kuantitatif dari produk kepada pelanggan.

4. Sistem distribusi, yaitu saluran perdagangan grosir dan eceran yang dilalui produk hingga mencapai konsumen akhir yang membeli dan menggunakannya.

5. Komunikasi pemasaran (promosi), yang meliputi periklanan, personal selling, promosi penjualan, direct marketing dan publick relations.

Menurut Kotler dan Keller (2008), umumnya tujuan pengembangan produk baru adalah:

1. Untuk memenuhi kebutuhan baru dan memperkuat reputasi perusahaan sebagai investor, yaitu dengan menawarkan produk yang lebih baru dari pada produk sebelumnya.

2. Untuk mempertahankan daya saing terhadap produk yang sudah ada, yaitu dengan jalan menawarkan produk yang dapat memberikan jenis kepuasan yang baru. Bentuknya bisa bertambah terhadap lini produk yang sudah ada maupun revisi terhadap produk yang telah ada.

Sedangkan menurut Alma (2002), terdapat beberapa alasan yang membuat perusahaan melakukan pengembangan produk, yaitu:

1. Untuk memenuhi keinginan konsumen.

2. Untuk menambah omzet penjualan.

3. Untuk mendayagunakan sumber-sumber produksi.

4. Untuk memenangkan persaingan.

5. Untuk meningkatkan keuntungan dengan pemakaian bahan yang sama. 
6. Untuk mendayagunakan sisasisa bahan.

7. Untuk mencegah kebosanan konsumen.

8. Untuk menyederhanakan produk pembungkus.

\section{Metode Penelitian}

Tujuan artikel ini adalah untuk mengkaji fenomena bisnis digital dimana terjadi pergeseran strategi pemasaran dari tradisional menuju digital dalam kegiatan usaha. Dalam penelitian ini digunakan penelitian kepustakaan yang dalam proses pengambilan datanya tidak terjun secara langsung tetapi dengan mengambil berbagai sumber referensi yang mendukung suatu penelitian. Teknik pengumpulan data dengan menyimak serta mencatat informasi penting.

Penelitian ini bersifat deskriptif. Ini dilakukan untuk dapat mengetahui dan mampumenjelaskan karakter dan variabel yang diteliti dalam situasi tertentu( Sekaran, 2006 ). Dalam artikel ini peneliti berusaha menjelaskan mengenai fenomena yang diakibatkan oleh pandemi covid19 khususnya di Indonesia yang mengakibatkan adanya pergeseran strategi bisnis tradisional menuju bisnis digital.

Jenis data yang digunakan adalah data kualitatif berupa penjelasan dan uraian yang diperoleh dari berbagai sumber dan literatur yang peneliti temukan berdasarkan tema terkait.

Adapula limitasi daripada artikel ini adalah kurangnya spesifikasi yang lebih mendetail mengenai tempat dan daerah kajian sehingga solusi yang dihasilkan sangat umum namun sangat substantif dengan menyesuaikan diri bersama pandemi covid-19.

\section{Hasil dan Pembahasan}

Saya melihat dalam teori bahwa strategi pemasaran pada umumnya memanfaatkan keadaan dimana penjualan dapat dilakukan dalam berbagai kondisi termasuk pasar. Di dalam pasar, penjual dan pembeli bertemu secara langsung melakukan interaksi sosial sehingga terjadilah proses jual beli. Dalam skala berikutnya proses jual beli yang terjadi dapat meningkatkan perekonomian suatu daerah

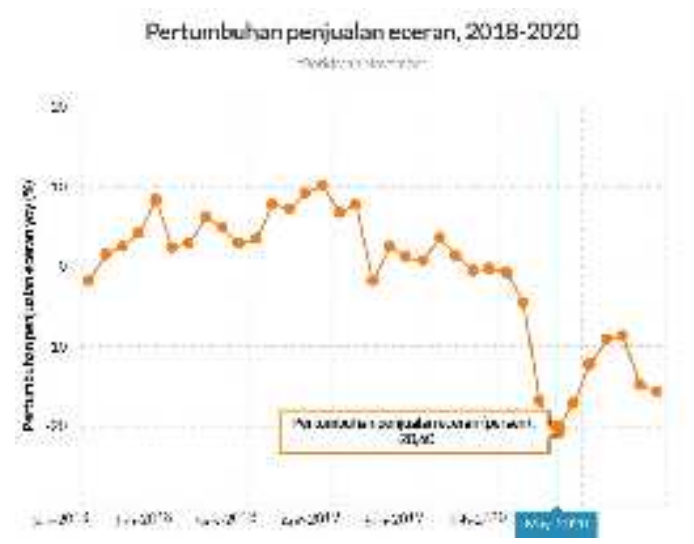

Gambar 1. Data Penjualan Eceran

Sedangkan dalam masa pandemi covid, kegiatan pasar terjadi penurunan secara drastis. Dalam gambar 1 dapat dilihat bahwa penjualan eceran menunjukkan penurunan tepat pada pandemi covid melanda Indonesia yaitu pada awal tahun 2020.

Blog Lokadata

(2020) menyebutkan dalam survei penjualan eceran yang dirilis Bank Indonesia (BI), Indeks Penjualan Riil (IPR) Oktober 2020 tercatat sebesar 183,5 atau tumbuh minus 14,9 persen secara tahunan, lebih dalam dari kontraksi pada September 2020 yang minus 8,7 persen secara tahunan.

Penurunan IPR pada Oktober dialami oleh mayoritas kelompok penjualan yang dipantau. BI mencatat IPR kelompok makanan, minuman, dan tembakau mengalami kontraksi 5,6 
persen secara tahunan di Oktober 2020. Padahal, pada September 2020, sektor ini hanya terkontraksi 3,1 persen secara tahunan.

Indeks peralatan informasi dan komunikasi juga terkontraksi lebih dalam dari minus 22,2 persen secara tahunan per September 2020 menjadi minus 30,9 persen secara tahunan per Oktober 2020. Begitu juga kelompok barang lainnya yang minus 51,8 persen secara tahunan pada September 2020 menjadi minus 53,5 persen secara tahunan pada Oktober 2020.

Hal ini mengindikasikan bahwa akan ada kerugian - kerugian yang diderita akibat pandemi ini. Sudah bukan isapan jempol belaka bahwa memang sebagian besar para penggerak bisnis mendapat pukulan besar dengan menurunnya permintaan dari masyarakat sehingga membuat perekonomian melemah.

\subsection{Strategi Pemasaran Bisnis Digital Di Masa Pandemi Covid-19.}

Dalam teori strategi pemasaran disebutkan bahwa ada tahapan yang harus dilaksanakan untuk efektivitas penjualan. Namun pandemi covid - 19 membuat dan mengharuskan tahap dan langkah pemasaran menjadi sia-sia. Bagaimana tidak, untuk bertemu secara langsung dan melakukan kontak sosial saja dilarang. Negara mengharuskan kita sebagai warga negara untuk mengikuti protokol kesehatan dengan menjaga jarak, tidak keluar rumah, berkerumun serta wajib memakai masker di tempat umum.

Kemudian melihatpada faktor segmentasi pasar, dalam Assauri (2011) menyebutkan adanya fokus pemasaran, yaitu pemasaran yang terkonsentrasi dan tidak terkonsentrasi. Pandemi ini membuat variasi atau marketing mix memjadi kurang efektif. Pandemi membuat kebutuhan akan masker, makanan dan obat-obatan menjadi sangat meningkat di mata masyarakat. Bahkan di awal merebaknya fenomena ini terjadi penumpukan - penumpukan barang yang dilakukan oleh sekelompok masyarakat, seperti masker dan vitamin $\mathrm{C}$ mengalami kelangkaan di pasar sehingga sebagian masyarakat kesulitan untuk mendapatkan varian barang tersebut.

Saya memperhatikan teori Tciptono dengan mengandalkan perencanaan produk yang juga sudah biasa dilakukan oleh para pebisnis. Namun dalam masa pandemi ini dipastikan perencanaan produk mengalami ketidak efektifan dalam implementasinya $\mathrm{Hal}$ ini disebabkan terjadinya penurunan permintaan dan persediaan barang dan jasa layaknya krisis ekonomi yang berkelanjutan terjadi di berbagai belahan dunia termasuk di Indonesia.

Berita Kompas dalam Kompas.com (2020) menyebutkan Indonesia mengonfirmasi kasus covid pertama pada awal Maret 2020. Sejak itu hampir seluruh sektor terdampak (tidak hanya kesehatan). Sektor ekonomi juga mengalami dampak serius akibat pandemi. Artikel Kompas tersebut memuat data BPS yang menyebutkan pertumbuhan ekonomi Indonesia pada kuartal 22020 minus 5,3 persen. Kemudian dalam data Kementerian Ketenaga kerjaan per 7 April 2020, akibat pandemi covid-19 tercatat sebanyak 39.977 perusahaan di sektor formal yang memilih merumahkan dan melakukan PHK terhadap pekerjanya. Rinciannya 873.090 pekerja dari 17.224 perusahaan dirumahkan, sedangkan 137.489 pekerja di PHK dari 22.753 perusahaan. Dilihat dari sebaran sektornya, perdagangan adalah sektor yang paling banyak mengalami pengurangan penyerapan tenaga kerja.

Kemudian Ketua Umum

Asosiasi Pengusaha Indonesia (Apindo) Hariyadi Sukamdani dalam Merdeka.com 
(2020) menyatakan di masa pandemi ini terjadi perubahan konsumsi masyarakat. Hal ini terlihat dari indeks kepercayaan konsumen menurun drastis pada kuartal ke 2 tahun 2020. Dia menjelaskan intensitas belanja masyarakat turun disebabkan oleh indeks rencana pembelian yang turun hingga 10,5 persen. Selain itu prioritas pengeluaran konsumen juga berubah. Mereka lebih mementingkan pada kebutuhan pokok listrik, obat dan vitamin serta paket dan pulsanya karena banyak digunakan untuk kegiatan online. Selain itu, di sisi barang konsumsi masyarakat juga menurun. Misalnya kegiatan makan diluar berkurang 84 persen, traveling menurun 80 persen yang terkait dengan pariwisata, dan akomodasi juga drop sangat jauh. Sementara itu, indeks kepercayaan konsumen juga menunjukkan penurunan yang cukup besar yakni menurun ke level 72,6 persen, karena present situation index turun tajam sementara expectation index relatif stabil. Fenomena ini menunjukkan bahwa harus dan akan ada perubahan dalam upaya memperbaiki angkat penurunan dari aspekaspek tersebut.

Strategi pemasaran yang pada awalnya dapat dilakukan dengan berbagai cara termasuk pertemuan, meeting, menjual secara langsung serta cara lainnya harus terhenti guna mencegah penularan virus corona tersebut. Pemasaran barang dan jasa dengan tanpa melalui kontak fisik adalah dengan cara memanfaatkan internet sebagai media iklan atau promosi. Bukan hanya promosi, namun dunia digital dapat dimanfaatkan untuk langsung melakukan transaksi jual beli tanpa harus kontak secara langsung antara penjual dan pembeli.

Menurut Simamora (2000), terdapat delapan (8) tahap yang harus dilalui dalam pengembangan produk baru seperti gambar berikut ini :

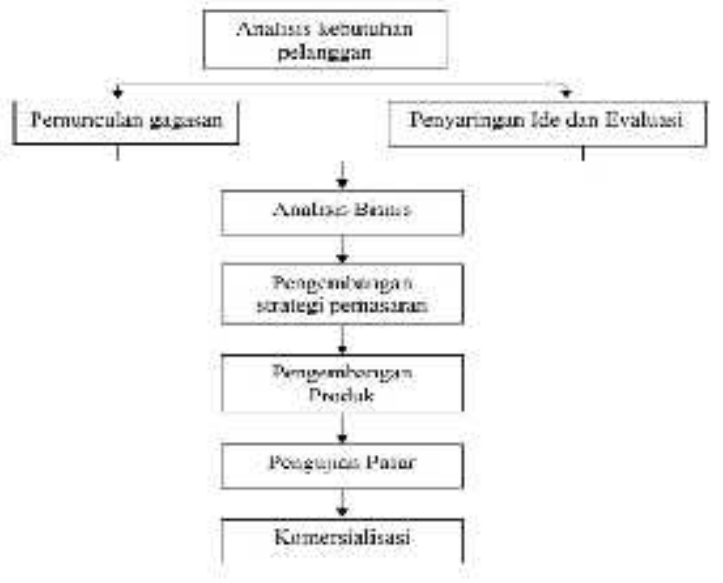

Gambar 2

Menurut gambar 2 di atas, salah satu tahap yang dilakukan dalam pengembangan produk baru adalah tahap ke 5 yaitu pengembangan strategi pemasaran. Menurut Simamora (2000) tujuan pengembangan strategi pemasaran adalah penyempurnaan rencana lebih lanjud pada tahap-tahap berikutnya yaitu bagaimana strategi pemasaran untuk mengenalkan produk baru ke pasar. Dalam tahap ini perusahaan melakukan pengembangan rencana strategi dimana strategi pemasaran lebih dahulu mengalami penyaringan.

Dalam melakukan pengembangan strategi pemasaran ada 3 bagian pokok, antara lain :

1. Menjelaskan ukuran struktur, perilaku pasar sasaran, posisi produk yang direncanakan, penjualan, pangsa pasar dan laba yang diinginkan dari lima tahun pertama.

2. Menggambarkan harga, strategi distribusi dan anggaran perusahaan yang direncanakan untuk produktersebut dalam tahun pertama.

3. Menjelaskan jumlah penjualan, sasaran laba dan strategi pemasaran selanjutnya.

Untuk menjelaskan struktur 
pasar dan produk yang direncanakan, harus menyesuaikan dengan situasi dan kondisi yang dialami oleh masyarakat. Ketika masyarakat sedang mengalami ketakutan mdan keterbatasan yang disebabkan oleh pandemi covid-19, ketika itu pula harus ada pergeseran strategi penjualan jika para pelaku pasar dan masyarakat tetap ingin mendapatkan kebutuhan yang mereka inginkan di masa pandemi. Situasi ini dimanfaatkan oleh masyarakat untuk dapat melanjudkan kegiatan bisnis namun dengan media yang berbeda yaitu melalui dunia digital atau online. Transaksi masyarakat secara online dapat dimanfaatkan untuk mengirim dan membeli atau menjual barang tanpa harus bertatap muka dan kontak sosial. Pengusaha ritel konvensional sangat merasakan kebutuhan masyarakatakan hal ini. Masyarakat tetap membutuhkan barang dan jasa namun mereka memilih berbelanja melalui HP dan laptop dengan dukungan koneksi internet sebagai sarana untuk bertransaksi. Hal ini dilakukan untuk mencegah penularan virus covid-19. Dunia digital juga dapat menjelaskan perdagangan dengan menggambarkan harga serta strategi yang tepat bagaimana cara menjual barang dan jasa untuk mengembalikan kepercayaan konsumen dengan berbelanja online.

Damiati (2017) menjelaskan peran sikap konsumen dapat membantu suatu kegiatan pemasaran yaitu dengan cara mengidentifikasi segmen berdasarkan manfaat, pengembangan produk baru dan evaluasi strategi promosi. Dalam hal ini situasi pandemi covid bukanlah akhir dari segalanya. Teknologi dan informasi harus dimanfaatkan dengan seksama. Contohnya jika seorang pebisnis melakukan bisnis di bidang kuliner nasi warteg. Penjual nasi di warteg tersebut mengalami penurunan omset yang disebabkan oleh pandemi. Maka keadaan ini harus dimanfaatkan oleh pebisnis untuk mengembangkan produk dan strategi promosi. Caranya yang pertama adalah dengan mengembangkan produk ke arah yang lebih luas dengan menjual lauk pak lain selain daripada nasi dengan cara identifikasi segmen pasar di daerah bisnis tersebut berada. Kedua melakukan perluasan strategi promosi warteg dengan mempromosikan makanannya melalui gojek, gofood, atau platform lainnya dengan memanfaatkan teknologi dan informasi.

Pemasar juga menggunakan perubahan sikap untuk mengevaluasi strategi promosinya. Misalnya selama ini sebuah toko diasosiasikan sebagai toko dengan citra yang memberi rasa aman dan tradisional. Asosiasi ini tertanam sangat kuat pada konsumen yang sudah tua. Tetapi saat ini toko tersebut ingin menyasar konsumen anak muda. Berdasarkan hasil repositioning, toko tersebut mengubah mindset dan karakternya dengan selalu mengikuti mode dan perkembangan zaman. Secara teknis toko ini melakukan penjualan eceran dan partai besar melalui online shop dengan memanfaatkan jasa pengiriman barang dan platform yang sudah ada. Tidak lupa untuk melakukan perancangan iklan yang menyampaikan kemampuan untuk melakukan perubahan tersebut agar konsumen mengetahui terobosan itu.

\section{Kesimpulan}

Pandemi Covid-19 telah merusak dan memporak-porandakan berbagai aspek kehidupan khususnya perekonomian. Sudah bukan isapan jempol belaka bahwa kita semua merindukan waktu-waktu dimana setiap orang dapat berinteraksi sosial dengan cara yang normal tanpa social distancing dan protokol kesehatan lainnya.

Namun dibalik peristiwa ini pasti ada solusi dan pelajaran yang diambil. Bisnis online sekarang semakin merebak dan berkembang pesat karena fenomena 
ini. Usaha penjualan online menjadi salah satu solusi di masa pandemi. Selain itu jenis usaha lain dapat dilakukan dengan gencar di masa pandemi seperti jasa pengiriman barang, penjualan kuliner secara online melalui platform gojek, gofood atau grab yang sudah tidak asing lagi di telinga kita. Memang usaha dan modal perlu dilakukan untuk memaksimalkan ikhtiar ini. Oleh karena itu peneliti mengambil kesimpulan berupa solusi optimis untuk mengembalikan kesehatan perekonomian di Indonesia yang selama ini melemah dikarenakan pandemi. Selain untuk mendapatkan penghasilan karena hilangnya sumber penghasilan akibat dari pemutusan hubungan kerja sementara bahkan permanen di masa pandemi. Beberapa masyarakat banyak juga yang memanfaatkan jualan kuliner online untuk sekedar mengisi kegiatan dirumah. Hal ini dapat merangsang kreativitas dan inovasi dalam berbisnis masyarakat, yang jika dijalankan dengan baik dan konsisten akan berdampak pada perbaikan ekonomi nantinya menuju masa transisi setelah pademi covid-19 berakhir.

\section{DAFTAR PUSTAKA}

Alma, Buchari. 2002. Manajemen Pemasaran dan Pemasaran Jasa. Bandung: Alfabeta.

Damiati ;Masdarini, Luh ; Suriani, Made. 2017. Perilaku Konsumen. Depok: PT. Raja Grafindo Persada.

Kompas.com (2020, 11Agustus). Pandemi Covid-19, Apa Saja Dampak pada sektor ketenaga kerjaan Indonesia. Diakses Pada 26 Juni 2021, dari https://www.kompas.com/tren/read /2020/08/11/102500165/pandemiCovid-19-apa-saja-dampak-pada- sektor-ketenagakerjaan-indonesia?page $=$ all

Kotler, Philipdan Keller, Kevin. 2008. Manajemen Pemasaran. Jakarta: Prenhallindo.

Lokadata.id. (2020, 14 Desember). Penjualan Ritel Akan Membaik Pada Dua Bulan Terakhir 2020. Diakses Pada 26 Juni 2021, dari https://penerbitdeepublish.com/cara -menulis-daftar-pustaka-dari website

Merdeka.com. (2020,26 Agustus). Apindo sebut indeks kepercayaan Konsumen Anjlok di Kuartal 2 2020. Diakses pada 27 Juni 2021, dari

https://www.merdeka.com/uang/ap indo-sebut-indeks-kepercayaankonsumen-anjlok-di-kuartal-ii2020.html

Rangkuti, Freddy. 2006. Analisis SWOT Teknik Membedah Kasus Bisnis. Jakarta: Gramedia Pustaka Utama.

Simamora, Henry. 2000. Manajemen Pemasaran Internasional. Jakarta: Salemba Empat.

Uma Sekaran, 2006. Metode Penelitian Bisnis. Jakarta : Salemba Empat.

Wijaya, Indra dan Iriani, S.S. 2013. Pengaruh Citra Merek Terhadap Loyalitas Konsumen. Jurnal Ilmu Manajemen, Vol 1 Nomor 3. 